\title{
Scope and determinant of career preferences for medical preclinical students at Udayana University
}

\author{
Escopo e determinante das preferências de carreira para estudantes de medicina pré-clínica na \\ Universidade de Udayana
}

Alcance y determinante de las preferencias profesionales de los estudiantes de medicina preclínica en la Universidad de Udayana

\begin{abstract}
The medical field has wide career preferences as the medical world develops, making it attractive for students to study medicine. The breadth of career preferences in the medical field exposes students to various career options according to their wishes and abilities. Insight into medical career preferences will help students determine the right medical career. This study aims to determine the determinants of career preferences of medical preclinical students in general in Indonesia. This study used a method descriptive cross-sectional. The data is the result of the questionnaire in accordance with the inclusion criteria of the sample. The number of samples obtained was 145 medical preclinical students at the Faculty of Medicine, Udayana University. From the results of the study, it was found that 138 students (95.2\%) chose a career as a clinician and 7 students $(4.8 \%)$ chose a career as a non-clinical doctor. Students who choose clinicians, choose a pediatrician and internal medicine specialist as many as 22 students (16.2\%). Pre-clinical blocks that are preferred by students are Behavior 87 students (60\%) and Endocrine 24 students (16.6\%). Parental background, cost, and time required for further education are not obstacles for respondents to choose their career preferences.
\end{abstract}

Keywords: Career preference; Career determination; Medical students; Medical career.

\section{Resumo}

$\mathrm{O}$ campo médico tem amplas preferências de carreira à medida que o mundo médico se desenvolve, tornando-o atraente para os alunos estudarem medicina. A amplitude das preferências de carreira na área médica expõe os alunos a várias opções de carreira de acordo com seus desejos e habilidades. A compreensão das preferências de carreira médica ajudará os alunos a determinar a carreira médica certa. Este estudo tem como objetivo determinar os determinantes das preferências de carreira de estudantes de medicina pré-clínica em geral na Indonésia. Este estudo utilizou um método descritivo transversal. Os dados são o resultado do questionário de acordo com os critérios de inclusão da amostra. O número de amostras obtidas foi de 145 alunos de medicina pré-clínica da Faculdade de Medicina da Universidade de Udayana. A partir dos resultados do estudo, constatou-se que 138 alunos (95,2\%) escolheram a carreira de médico e 7 alunos $(4,8 \%)$ escolheram a carreira de médico não clínico. Os alunos que optam pelo clínico optam pelo pediatra e pelo especialista em clínica médica em até 22 alunos (16,2\%). Os bloqueios préclínicos preferidos pelos alunos são Comportamento 87 alunos (60\%) e Endócrino 24 alunos (16,6\%). A origem dos pais, o custo e o tempo necessário para a educação superior não são obstáculos para que os entrevistados escolham suas preferências de carreira.

Palavras-chave: Preferência de carreira; Determinação de carreira; Estudantes de medicina; Carreira médica. 


\begin{abstract}
Resumen
El campo de la medicina tiene amplias preferencias profesionales a medida que se desarrolla el mundo de la medicina, lo que lo hace atractivo para los estudiantes estudiar medicina. La amplitud de las preferencias profesionales en el campo de la medicina expone a los estudiantes a varias opciones profesionales de acuerdo con sus deseos y habilidades. La comprensión de las preferencias de la carrera médica ayudará a los estudiantes a determinar la carrera médica adecuada. Este estudio tiene como objetivo determinar los determinantes de las preferencias profesionales de los estudiantes de medicina preclínica en general en Indonesia. Este estudio utilizó un método descriptivo transversal. Los datos son el resultado del cuestionario de acuerdo con los criterios de inclusión de la muestra. El número de muestras obtenidas fue de 145 estudiantes de preclínica médica de la Facultad de Medicina de la Universidad de Udayana. A partir de los resultados del estudio, se encontró que 138 estudiantes $(95,2 \%)$ eligieron una carrera como clínico y 7 estudiantes $(4,8 \%)$ eligieron una carrera como médico no clínico. Los estudiantes que eligen a los médicos, eligen un pediatra y un especialista en medicina interna hasta 22 estudiantes (16,2\%). Los bloques preclínicos que prefieren los estudiantes son Behavior 87 estudiantes (60\%) y Endocrine 24 estudiantes (16.6\%). Los antecedentes de los padres, el costo y el tiempo necesarios para la educación superior no son obstáculos para que los encuestados elijan sus preferencias profesionales.
\end{abstract}

Palabras clave: Preferencia de carrera; Determinación de carrera; Estudiantes de medicina; Carrera médica.

\title{
1. Introduction
}

In developing countries such as Indonesia, doctors are still a profession that has great appeal and interest compared to other professions. Some of the reasons for this include the wide range of available job opportunities and the wide range of career preferences that medical students can still take later. Talking about career preferences that are quite broad, create a condition where medical students in pursuing their education are required to know and know more about the available medical careers (Leduc et al., 2011). This is important for medical students to consider in determining their future career preferences, because sometimes undergraduate students don't think about it until they graduate from medical education (Vanasse et al., 2011). However, there are also conditions where new students and even prospective medical education applicants have strong career views and preferences for their future career in the medical world (Rodriguez et al., 2015). This condition is also an attraction for further research on matters that affect career preferences in medical students. Currently, many studies have been conducted and some of them mention that individual characteristics, family background, and associations of certain personality types greatly influence this (Bhat et al., 2012).

Current developments in the health care delivery system and advances in medical technology make the interprofessional health debate still debated (Yousef et al., 2009). Coupled with these conditions, an understanding of the importance of determining career preferences for medical students is important in setting priorities, planning educational programs, and providing adequate health services by medical education providers (Yamazaki et al., 2013). Therefore, determining the right career preferences by medical students plays an important role in the future workforce in the health care system (Cleland, 2012).

The number of medical students each year will also continue to increase along with the increase in the existing Faculty of Medicine, but the understanding of the importance of career preferences for medical students is still lacking (Rizma et al., 2014). Therefore, this literature review as an explanation of career preferences and determinant that influence the decisions of medical students in choosing their careers.

\section{Research Methods}

The method of this research is an observational study design using aapproach descriptive cross-sectional study in the form of quantitative to find out the career preferences and determinant that affect the career preferences of medical preclinical students at the Faculty of Medicine, Udayana University. The research sample came from preclinical students at the Faculty of Medicine, Udayana University who had entered the research inclusion criteria by taking samples, namely consecutive sampling 
during the research period, which was 6 months. The research instrument used a questionnaire that had been adjusted based on previous research conducted in 2014 and given online via googleform. The keywords for this research are career preference, career determination, medical students, medical career.

\section{Results and Discussion}

In this study, a total sample of 145 respondents came from preclinical medical students at Faculty of Medicine, Udayana University who already met the criteria as inclusion sample criteria. All respondents have been given a questionnaire related to their career preferences and determinant that influence the respondents' career preferences through google form an online. The description of the scope of the chosen career preferences consists of clinical and non-clinical fields.

Table 1 shows respondents' choices in choosing to continue their education after graduating from the profession and the choice between clinical or non-clinical fields. The respondents who chose to continue their education after graduating from the profession were 142 people (97.9\%) and not as many as 3 people (2.1\%). Respondents who chose the field of clinicians as many as 138 people $(95.2 \%)$ and non clinicians as many as 7 people $(4.8 \%)$.

Table 1. Respondent's Choices to Continue Their Education After Graduating.

\begin{tabular}{cccc}
\hline \multirow{2}{*}{ Variable } & Category & Q & Quantity \\
\cline { 3 - 4 } & & 142 & Percent (\%) \\
\hline Continuing Post-Graduation & Yes & 3 & $97,9 \%$ \\
Education & No & 138 & $2,1 \%$ \\
\hline \multirow{2}{*}{ Preferred Field of Medicine } & Clinical & 7 & $95,2 \%$ \\
& Non-Clinical & & $4,8 \%$ \\
\hline
\end{tabular}

Source: Authors.

Table 2 shows the clinician's career preferences, namely the specialist career chosen by the respondent. It was found that the most specialist career preferences were internal medicine specialists as many as 22 people (16.2\%), pediatrics as many as 22 people $(16.2 \%)$, obstetrics and gynecology as many as 19 people (14.4\%), and psychology/psychiatry as many as 15 people (11.1\%). 
Table 2. The Clinician's Career Preferences.

\begin{tabular}{lcc}
\hline \multicolumn{1}{c}{ Specialist Field } & n & Percent (\%) \\
\hline Pediatrician & 22 & $16,2 \%$ \\
Internist & 22 & $16,2 \%$ \\
Gynecologist & 19 & $14,4 \%$ \\
Psychiatrist & 15 & $11,1 \%$ \\
Dermatovenereologist & 14 & $10,5 \%$ \\
Anesthesiologist & 9 & $6,6 \%$ \\
Surgeon & 6 & $4,4 \%$ \\
Orthopedic & 6 & $4,4 \%$ \\
Cardiologist & 6 & $4,4 \%$ \\
Neurologist & 4 & $2,9 \%$ \\
ENT Specialist & 4 & $2,9 \%$ \\
Ophthalmologist & 3 & $2,2 \%$ \\
Radiologist & 2 & $1,5 \%$ \\
Pulmonologits & 2 & $1,5 \%$ \\
Plastic Surgeon & 1 & $0,7 \%$ \\
Anatomy Patology & 0 & 0 \\
Clinical Microbiology & 0 & 0 \\
Clinical Patology & 0 & $100 \%$ \\
\hline Total & &
\end{tabular}

Source: Authors.

Table 3 shows the career preferences of respondents in the form of careers in the non-clinical field, which shows as many as 32 respondents chose with the most choices in hospital management as many as 15 people (46.8\%), followed by entrepreneurs as many as 7 people $(22 \%)$.

Table 3. The Non-Clinical's Career Preferences.

\begin{tabular}{lcc}
\hline \multicolumn{1}{c}{ Non-Clinical Field } & n & Percent (\%) \\
\hline Hospital Management & 15 & $46,8 \%$ \\
Entrepreneur & 7 & $22 \%$ \\
Master of Health Sciences & 6 & $18,7 \%$ \\
Researcher & 4 & $12,5 \%$ \\
\hline Total & 32 & $100 \%$ \\
\hline
\end{tabular}

Source: Authors.

The determinants of the career preferences of preclinical medical students consist of parents' occupations, the influence of choosing to study medicine, preferred preclinical learning blocks, and costs required for further education. Table 4 shows the background of the respondent's parents in the form of father's occupation, mother's occupation, and the average income of both parents per month. The highest number of father jobs were non-medical as many as 108 people (74.5\%) followed by medical as many as 31 people $(21.4 \%)$, and the highest maternal occupation was non-medical as many as 109 
people $(75.2 \%)$ followed by medical as many as 24 people $(16.6 \%)$. The average income of both parents per month is $>5$ million as many as 98 people $(67.6 \%)$ and $<5$ million as many as 47 people $(32.4 \%)$.

Table 4. The Background of The Respondent's Parents.

\begin{tabular}{cccc}
\hline \multirow{2}{*}{ Variable } & Category & Q & Percent (\%) \\
\cline { 3 - 4 } Father's Occupation & Medical & 31 & $21,4 \%$ \\
& Non Medical & 108 & $74,5 \%$ \\
\hline \multirow{2}{*}{ Mother's Occupation } & Medical & 24 & $16,6 \%$ \\
& Non Medical & 109 & $75,2 \%$ \\
\hline \multirow{2}{*}{ Monthly Parent's Income } & $>5$ Million & 98 & $67,6 \%$ \\
& $<5$ Million & 47 & $32,4 \%$ \\
\hline
\end{tabular}

Source: Authors.

Table 5 shows the influence of choosing to study at the Faculty of Medicine. The effect was obtained only from the wishes of oneself as many as 62 people (42.8\%), the influence only from the wishes of parents as many as 20 people (13.8\%), and the influence of both as many as 63 people $(43.4 \%)$. (See Table 5, next).

Table 5. The Influence of Choosing to Study at Faculty of Medicine.

\begin{tabular}{lcc}
\hline The Influ ence of Choosing to Study at Faculty of Medicine & n & Percent (\%) \\
\hline Only Self Des ire & 62 & $42,8 \%$ \\
Only Parents W ish & 20 & $13,8 \%$ \\
Both W ishes & 63 & $43,4 \%$ \\
\hline Total & 145 & $100 \%$ \\
\hline
\end{tabular}

Source: Authors.

Table 6 shows a preferred learning block materials during pre-clinical. The most preferred learning blocks were in the block Behavior as many as 87 people (60.0\%), followed by the Endocrine block as many as 24 people (16.6\%), and the Hematology block as many as 9 people $(6.2 \%)$. 
Table 6. Preferred Learning Block Materials During Pre-Clinical.

\begin{tabular}{lcc}
\hline \multicolumn{1}{c}{ Pre Clinical Block } & n & Percent (\%) \\
\hline Behavior & 87 & $60 \%$ \\
Endokrin & 24 & $16,6 \%$ \\
Hematology & 9 & $6,2 \%$ \\
Infectious Dis ease & 7 & $4,8 \%$ \\
Skin \& Hearing System & 7 & $4,8 \%$ \\
Growth \& Development & 4 & $2,8 \%$ \\
Alimentary & 3 & $2,1 \%$ \\
Respiratory Sy stem & 2 & $1,4 \%$ \\
Imunology & 2 & $1,4 \%$ \\
\hline Total & 145 & $100 \%$ \\
\hline
\end{tabular}

Source: Authors.

Table 7 shows the cost of further education required, and the length of time for further education chosen. There were 137 respondents $(94.5 \%)$ who chose specialist advanced education with a cost range of 15-18 million per semester and 8 people chose a master's degree in health sciences with a cost range of 6.5-13.5 million per semester. (5.5\%). Respondents who chose specialist advanced education with a span of 5-11 semesters of education were 138 people (95.2\%) and 7 people (4.8\%). (See Table 7, next).

Table 7. The Cost Required and The Length of Time For Further Education Chosen.

\begin{tabular}{clcc}
\hline \multirow{2}{*}{ Variable } & \multicolumn{1}{c}{ Category } & \multicolumn{2}{c}{ Quantity } \\
\cline { 3 - 4 } & & Specialist (15-18 million) & Percent (\%) \\
\hline \multirow{2}{*}{$\begin{array}{c}\text { The Cost of Further } \\
\text { Education Required }\end{array}$} & Master of Health Sciencie (6,5-13,5 million) & 137 & $94,5 \%$ \\
& Total & 145 & $100 \%$ \\
\hline The Length of Time & Specialist (5-11 semester) & 138 & $95,2 \%$ \\
for Further Education & Master of Health Science (4 s emester) & 7 & $4,8 \%$ \\
\hline Chosen & Total & 145 & $100 \%$ \\
\hline
\end{tabular}

Source: Authors.

\section{Discussion}

The scope of respondents' career preferences after graduating from the profession in table 1 shows that as many as 97.9\% said they wanted to continue their education and as many as $95.2 \%$ of respondents chose the field of clinician to continue their career. These results are in accordance with the results of research in 2016 which showed students who chose a clinician career were the most voters with a percentage above 90\% (Andarwati et al., 2016; Mardhiyah et al., 2016). This is due to the view of the majority of the community that the doctor is a job that is only in the field of clinicians or is related to direct treatment to patients (Kemenkes RI, 2011).

Judging from the results of the data obtained in table 2 and table 3, it shows that the description of the career preferences of preclinical medical students prefers a clinician career as a specialist which reaches 135 (93.1\%) people, compared to non-clinical careers such as teaching staff/lecturers, hospital management, and researchers. This result is in 
accordance with the results of research in 2014 which showed that $83.8 \%$ of medical students in Indonesia chose to continue their career like a specialist (Rizma et al., 2014). This result is also supported by next research in 2015 at the Islamic University of Bandung which shows that $85 \%$ of medical students prefer a career like a specialist (Eka et al., 2015). From table 2 , it can be seen that the most selected specialist fields are pediatric and internal medicine specialists as many as 22 people (16.2\%), followed by obstetrics and gynecology specialists as many as 19 people (14.4\%), and psychiatric/psychiatry specialists. as many as 15 people $(11.1 \%)$. These results are in accordance with the results of research in 2016 which showed that pediatrics, internal medicine, and obstetrics-gynecology are the specialist fields that are most in demand by specialist career voters (Andarwati et al., 2016).

The determinant of the respondents' career preferences, namely the parental background, which is shown in table 4, shows that the work of parents as non-medical is the highest with the percentage of non-medical fathers being $74.5 \%$ and nonmedical mothers being $75.2 \%$. These results are in accordance with research in 2016 which shows that the work of parents as medical personnel is only 13\% (Andarwati et al., 2016). Judging from the income of parents per month, it can be seen that the income of parents is more than 5 million per month as much as $67.6 \%$ shows that there are more students who have a high economic level. These results are in accordance with the results of researchs in 2014 and 2016 which show that parents with a high economic level are more numerous, due to the large tuition fees required in medicine (Rizma et al., 2014; Andarwati et al., 2016).

Determinants of the influence of students choosing to study at the Faculty of Medicine that come from only their own desires compared to those of their parents and themselves do not look much different, which can be seen in table 5. This is in accordance with the results of research in 2014 which shows that there is a significant relationship between the attractiveness period and the desire to study at the Faculty of Medicine with the career preferences of medical students (Rizma et al., 2014). In table 7 which shows the determinants of the cost and travel time of education required, it can be seen that the considerable cost and long travel time of education are not obstacles for respondents in choosing a career as a specialist. It can be seen that 94.5\% and $95.2 \%$ of respondents still choose a career as a specialist, even with the high cost and long education time.

Table 6 shows the determinants of the pre-clinical block material most preferred by pre-clinical medical students. From these data it can be seen that the most preferred block is the block Behavior as much as $60 \%$, followed by Endocrine block as much as $16.6 \%$, and Hematology block as much as $6.2 \%$. These results show conformity with the results in table 2 regarding the description of the selected specialist fields, where the four most selected specialist fields include internal medicine and psychiatry/psychiatry. Block Behavior relating to the specialist field of psychiatry/psychiatry, while the Endocrine and Hematology block relates to the field of internal medicine specialist.

\section{Conclusions}

This study shows the scope and determinants of career preferences for pre-clinical medical students at Udayana University. It was found that 138 people (95.2\%) chose a career preference as a clinician with the highest number of specialists in pediatrics and internal medicine specialists as many as 22 people $(16.2 \%)$, followed by specialists in obstetrics and gynecology as many as 19 . people (14.4\%), and psychiatric specialists as many as 15 people $(11.1 \%)$. There is a match between the most specialist fields and the most preferred preclinical block material, namely theblock Behavior as many as 87 people (60\%), Endocrine block as many as 24 people (16.6\%), and Hematology block as many as 9 people (6.2\%). The description of parental background, cost and time required for further education does not appear to be an obstacle for respondents to choose their career preferences. 


\section{Reference}

Andarwati P, Syarifah N, dan Arief, P. N. (2016). Motivasi dan Pilihan Karir Mahasiswa Tingkat Akhir Fakultas Kedokteran Universitas Airlangga, Surabaya, Buletin Penelitian Sistem Kesehatan, 19(2), 71-165.

Awallia, D. (2015). Kumpulan Situs Jurnal Kesehatan dan Keperawatan. http://dellyawallia.web.unej.ac.id

Cleland J. (2012). Associations Between Medical School and Career Preferences in Year 1 Medical Students in Scotland, 46, 473-84.

Glavin, K. W., Richard, G. V., \& Porfeli, E. J. (2009). Predictive Validity of The Medical Specialty Preference Inventory. Journal of Vocational Behavior, 74, $128-133$.

Glynn, R. W., \& Kerin, M. J. (2010). Factors Influencing Medical Students and Junior Doctors in Choosing A Career in Surgery. The Surgeon, Journal of The Royal Collages of Surgeons of Edinburgh and Ireland, 8, 187-191.

Herdinta Y., Irfanuddin M., \& Budi A. (2014). Persepsi Mahasiswa dan Dosen Tentang Ketercapaian Kompetensi Dasar dan Klinis Pendidikan Dokter di Fakultas Kedokteran Universitas Sriwijaya. Jurnal Kedokteran dan Kesehatan, 1 (1), 26-32.

Jagsi, R., Grifht, K. A., DeCastro, R.A. \& Ubel, P. (2014). Sex, Role Model, and Specialty Choices Among Graduates of US Medical Schools. Journal of American Collage of Surgeon, 218(3), 345-52.

Kaufman, S. B. (2013). Beyond Talent or Practice. Oxford University Press. The Complexity of Greatness, 464-470.

Kementrian Kesehatan Republik Indonesia. (2011). Rencana Pembangunan Tenaga Kesehatan Tahun 2011 - 2025. Jakarta: Kementrian Kesehatan Republik Indonesia, 6.

Maulidira, F., Syakurah, R. A, Fadilah, M. \& Aulia, H. (2015). Pengaruh Role Model Terhadap Pilihan Karir Pada Mahasiswa Fakultas Kedokteran. Jurnal Pendidikan Kedokteran Indonesia, 4 (2), 76-81.

Mardhiyah I, Oktadoni S, T. A., Larasati, dan Rifka. (2016). Studi Kualitatif Faktor - Faktor Yang Mempengaruhi Pemilihan Karir Pada Mahasiswa Kedokteran dan Dokter Internsip di Bandar Lampung, JK Unila, 1 (2), 82-272.

Milan, L. R., Azevedo, R. S., Rossi, E., Neves de Marco, L. N., Milan, M. P. B. \& Vaz de Arruda, P. C. (2005). What is Behind a Student's Choices for Becoming a Doctor. Clinics, 60 (2), 50-143.

Nicole, L., Vanasse, A., Scott, S., Orzanco, M. G. \& Dogma, J. M. (2011). The Career Decision-Making Process of Medical Students and Residents and Choice of Specialty and Practice Location: How Does Postgraduate Medical Education Fit In?. The Future of Medical Education in Canada, 22, 4-9.

Syakurah, R. A., Sari,D. A., Riansyah, D. \& Yolanda, P. (2014). Determinan Pilihan Karir Mahasiswa Fakultas Kedokteran Sebagai Spesialis di Indonesia. Jurnal Pendidikan Kedokteran Indonesia, 3 (2), 132-135.

Rodriguez C, Lopez-Roig S, Pawlikowska T, Schweyer F. X., Belanger E., Pas-tor-Mira. (2015). Impact of Academic Factor to Identified Medical Students with Discipline of Familly Medicine. Acad Med, 90, 660-670.

Secondira V, Retno G, Suhoyo Y. (2009). Faktor-faktor yang Memengaruhi Mahasiswa Fakultas Kedokteran Universitas Gadjah Mada untuk Melaksanakan Pembelajaran yang Konstruktif, Mandiri, Kolaboratif dan Kontekstual dalam Problem-Based Learning . Jurnal Pendidikan Kedokteran dan Profesi Kesehatan Indonesia, 4(1), 32-45.

Scott, A., Joyce, C., Cheng, T. \& Wang, W. (2013). An Evidence Check Rapid Review for The NSW Ministry of Health. Medical Career Path Decision, 7-23.

Smitha, B., D’Souza, L. \& Fernandes, J. (2012). Factors Influencing The Career Choices of Medical Graduates, $49,482-9$.

Utari Nur Alifah, Rohmaningtyas Hidayah Setyaningrum, Maryani. (2016). Hubungan Pengetahuan Pilihan Karir Kedokteran dengna Motivasi Akademik (Studi pada Mahasiswa Program Studi Kedokteran Fakultas Kedokteran Universitas Sebelas Maret Surakarta). Nexus Pendidikan Kedokteran dan Kesehatan, $5(2), 84-85$.

Yamazaki, Y. \& Takanori, U. (2013). Japanese Medical Students’ Interest Basic Science: A Questionnaire Survey of a Medical School in Japan. Tohoku J Exp Med. 229(2):129-36. 10.1620/tjem.229.129.

Khader, Y., Al-Zoubi, D., Amarin, Z., Alkafagei, A., Khasawneh, M., Burgan, S., El Salem, K. \& Omari, M. (2009). Factor Affecting Medical Students in Formulating Their Specialty Preference in Jordan. BMC Medical Education, 2-6. 